\title{
ANALISIS TINDAK TUTUR DALAM NOVEL PEREMPUAN BERKALUNG SORBAN KARYA ABIDAH EL KHALIEQY
}

\section{Farah Nur Fakhriyah}

Pendidikan Bahasa dan Sastra Indonesia, Fakultas Ilmu Tarbiyah dan Keguruan, UIN Syarif Hidayatullah Jakarta

e-mail: farahnurfakhriyah@gmail.com

\begin{abstract}
Abstrak: Penelitian ini bertujuan untuk mendeskripsikan atau menjelaskan tindak tutur, yakni tindak tutur lokusi, ilokusi, dan perlokusi. Penelitian ini menggunakan metode deskriptif kualitatif. Novel Perempuan Berkalung Sorban karya Abidah El Khalieqy dijadikan sumber data sebagai objek penelitian ini. Data yang dibahas ialah: (1) tindak tutur dan fungsinya yang juga dikaitkan dengan konteks, jarak sosial, dan budaya yang terdapat dalam novel Perempuan Berkalung Sorban karya Abidah El Khalieqy, (2) jenis tindak tutur lokusi, tindak tutur ilokusi (representatif, direktif, deklaratif, ekspresif, dan komisif), dan tindak tutur perlokusi (3) tuturan yang digunakan pada penelitian ini adalah tuturan yang dituturkan oleh tokoh dalam novel, dan narasi novel, data yang digunakan disesuaikan dengan tindak tutur yang akan diteliti.
\end{abstract}

Kata Kunci:Tindak tutur, lokusi, ilokusi, perlokusi, novel. 


\title{
ANALYSIS OF SPEECH ACTS IN THE NOVEL PEREMPUAN BERKALUNG $S O R B A N$ BY ABIDAH EL KHALIEQY
}

\section{Farah Nur Fakhriyah}

Education Language and Indonesia, Literature Science Faculty Tarbiyah and Teacher Training, UIN Syarif Hidayatullah Jakarta e-mail: farahnurfakhriyah@gmail.com

\begin{abstract}
This study aims to describe or explain speech acts, namely speech acts of locution, illocution, and perlocution. This study used descriptive qualitative method. Abidah El Khalieqy's novel, Perempuan Berkalung Sorban was used as a source of data as the object of this research. The data discussed are: (1) speech acts and their functions which are also related to context, social distance, and culture in Perempuan Berkalung Sorban Abidah El Khalieqy's, (2) types of locutionary speech acts, illocutionary speech acts (representative, directive, declarative, expressive, and commissive), and perlocutionary speech acts (3) the utterances used in this study are utterances spoken by characters in the novel, and novel narratives, the data used are adjusted to the speech acts to be studied.
\end{abstract}

Keywords: Speech act, locution, illocution, perlocution, novel. 


\section{A. PENDAhuluan}

Bahasa ialah sistem tanda bunyi yang disepakati untuk digunakan oleh para anggota kelompok masyarakat tertentu dalam bekerja sama, berkomunikasi, dan mengidentifikasi diri. Bahasa adalah sebuah sistem, sebuah sistem tanda dan bunyi. Bahasa juga digunakan agar setiap orang dapat bekerja sama dan berkomunikasi. Bahasa juga bersifat produktif, unik, dan universal (Kushartanti, 2007:3-5). Bahasa dalam hal ini berkaitan dengan penelitian yang dibahas, yaitu penelitian pragmatik yang di dalamnya terdapat tindak tutur lokusi, ilokusi, dan perlokusi.Tindak tutur pada penelitian ini diteliti menggunakan data yang ada di dalam karya sastra Indonesia. Karya sastra yang digunakan sebagai sumber penelitian yakni novel.

Menurut Nurgiyantoro (2017:4), karya fiksi dalam sastra merupakan sebuah cerita, dan karenanya terkandung juga di dalamnya tujuan memberikan hiburan kepada pembaca di samping adanya tujuan estetik. Membaca sebuah karya fiksi berarti menikmati cerita, menghibur diri untuk memperoleh kepuasan batin, dan sekaligus memperoleh pengalaman kehidupan. Namun, betapapun syaratnya pengalaman dan permasalahan kehidupan yang ditawarkan, sebuah karya fiksi haruslah tetap merupakan cerita yang menarik, tetap merupakan bangun struktur yang koheren, dan tetap memunyai tujuan estetik. Sedangkan, menurut Warisman (2016:109) novel merupakan karangan prosa panjang yang merangkai cerita kehidupan seseorang dengan orang-orang yang berada di sekelilingnya. Novel merupakan sebuah prosa naratif fiksional yang panjang dan kompleks yang menggambarkan secara imajinatif pengakaman manusia melalui rangkaian peristiwa yang saling berhubungan dengan melibatkan sejumlah orang (karakter) di dalam setting (latar) yang spesifik.

Menurut Leech (dalam Siddiq 2019:273), dewasa ini topik "Pragmatik" sangat dikenal dalam linguistik, padahal sebelumnya pragmatik lebih banyak diperlakukan sebagai sesuatu yang dapat dengan mudah dilupakan keberadaannya. Namun saat ini, disadari bahwa sifat bahasa dapat benar-benar dimengerti melalui studi mengenai pragmatik, yaitu bagaimana bahasa digunakan dalam komunikasi. Faridah dalam Siddiq (2019) juga menambahkan, disamping itu fungsi pragmatis adalah fungsi yang diacu oleh maksud tuturan di dalam pemakaiannya untuk berkomunikasi antar penutur.

Suatu tindak tutur merupakan suatu entitas yang sifatnya menjadi fokus dalam kajian pragmatik, sehingga tindak tutur menjadi dasar untuk analisis topik pragmatik yang lain, seperti anggapan, implikatur dalam percakapan, prinsip maksim kerja sama, prinsip kesantunan, dan lain-lain.

Wibowo lihat Austin (2009:9), tidak tutur dibagi ke dalam tiga jenis, yakni (a) tindak lokusi (locutionary acts), tidak ilokusi (illocutionary acts), dan tindak perlokusi (perlocutionary acts). Tindak lokusi merupakan tindak tutur penutur dalam menyampaikan sesuatu yang pasti sekalipun tidak ada keharusan bagi si punutur untuk melaksanakan isi tuturannya. Austin menggolongkan tindak lokusi ke dalam tiga subjenis: (a) tindak fonetis (phonetic act), yakni tidak mengucapkan bunyi (fonem) tertentu, (b) tindak fatis (phatic act), yakni tindak tutur dengan mengucapkan kosakata tertentu dengan membentuk suatu gramatika tertentu secara langsung, misalnya, "Media massa kita belakangan ini berkesan makin vulgar," ujar Kepala Sekolah; dan (c) tindak retis (rhetic act), yakni tindak tutur dengan tujuan melaporkan apa yang dituturkan si penutur secara tidak langsung, misalnya "Kepala Sekolah mengatakan bahwa media massa kita belakangan ini berkesan makin vulgar". 
Searle (dalam Rendro 2010: 217-218), lebih memantapkan lagi pendapat Austin, mengatakan bawa semua ujaran pada hakikatnya adalah tindakan ilokusi yakni apa yang dapat dilakukan penutur dengan menggunakan bahasa. Dia membagi tindak tutur menjadi lima sebagai berikut:

1. Representatif yaitu tindak tutur yang mengikat penutur pada kebenaran atas apa yang dikatakannya (misal: menyatakan, melaporkan, mengajukan, menyebutkan).

2. Direktif yakni tindak tutur yang dilakukan penutur dengan maksud agar si pendengar melakukan tindakan yang disebutkan di dalam ujaran itu (misal: menyuruh, memohon, menuntut, menyarankan, menentang).

3. Ekspresif yaitu tindak tutur yang dilakukan dengan maksud agar ujarannya sebagai evaluasi tentang hal yang disebutkan didalan ujaran itu (misal: memuji, mengucapkan terima kasih, mengkritik, mengeluh).

4. Komisif yakni tindak tutur yang mengikat penuturnya untuk melaksanakan apa yang disebutkan dalam ujarannya (misal: berjanji, bersumpah, mengancam).

5. Deklaratif yakni tindak tutur yang dilakukan si penutur untuk menciptakan hal yang baru (misal: memutuskan, melarang, membatalkan, mengizinkan, memberi maaf).

Selanjutnya, Wibowo (2009:9-10) menjelaskan bahwa tindak ilokusi merupakan tindak tutur penutur yang hendak menyatakan sesuatu dengan menggunakan suatu daya yang khas, yang membuat si penutur bertindak sesuai dengan apa yang dituturkannya. Dalam penegasan lain, tindak ilokusi adalah tindak dalam mengatakan sesuatu (performatif) yang berlawanan dengan tindak dalam mengatakan sesuatu karena di dalamnya terkandung suatu kekuatan yang mewajibkan si penutur melaksanakan apa yang dituturkannya. Austin membagi tindak ilokusi ke dalam lima subjenis: (a) verdikatif (verdikatives), tindak tutur yang ditandai oleh adanya keputusan yang bertalian dengan benar-salah, misalnya "Al Amin Nasution dituduh korupsi"; (b) eksertif (exerctives), tindak tutur yang merupakan akibat adanya kekuasaan, hak, atau pengar misalnya "Saya meminta anda untuk memeriksa siapapun tanpa pandang bulu," ujar Presiden kepada Jaksa Agung; (c) komisif (commissives), tindak tutur yang ditandai oleh adanya perjanjian atau perbuatan yang menyebabkan si penutur melakukan sesuatu, (d) behabitif (behabitives), tindak tutur yang mencerminkan kepedulian sosial atau rasa simpati, (e) ekspositif (expositive), tindak tutur yang digunakan dalam menyederhanakan pengertian atau definisi yang berasal dsri referensi tertentu.

Sedangkan, menurut Umaroh (2017:26) tindakan perlokusi berarti melakukan suatu tindakan dengan mengatakan sesuatu. Tindak perlokusi menghasilkan efek atau hasil, yaitu hasil atau efek yang ditimbulkan oleh ungkapan itu pada pendengar, sesuai dengan situasi dan kondisi pengucapan kalimat itu. Tanggapan tersebut tidak hanya berbentuk kata-kata, tetapi juga berbentuk tindakan atau perbuatan. Efek atau daya pengaruh ini dapat secara sengaja atau tidak sengaja dikreasikan oleh penuturnya.

Novel yang digunakan pada penelitian ini adalah novel Perempuan Berkalung Sorban karya Abidah El Khalieqy yang berlatar pesantren. Tokoh yang terdapat dalam novel tersebut di antaranya Nisa, Samsudin, Aisyah, Lek Khudori, Mbak Kalsum, Mbak Maryam, Kiai Hanan Abdul Malik, Istri Kiai Hanan AbdulMalik, Rizal, Wildan, dan lain-lain. Novel Perempuan Berkalung Sorban ini mengangkat isu perjododohan dalam islam, yaitu dalam lingkungan pesantren. Diceritakan Nisa seorang gadis anak dari Kiai Hanan Abdul Malik yang dijodohkan dengan Samsudin yang merupakan anak dari teman Kiai Hanan Abdul 
Malik. Lalu, dalam pernikahan Nisa dan Samsudin mereka tidak bahagia seperti yang diharapkan oleh keluarga mereka. Sejak remaja, Nisa menyukai Lek Khudori yang merupakan saudara jauhnya. Hingga akhirnya orang tua Nisa mengetahui apa yang dirasakan oleh anaknya selama masa pernikahan. Awalnya orang tua Nisa tidak merestui hubungan antara Nisa dan Lek Khudori, tetapi akhirnya mereka merestui. Abidah El Khalieqy adalah penulis wanita yang mengangkat tema feminisme pada novel-novelnya.

Penelitian mengenai tindak tutur tidak hanya dilakukan dalam wawancara langsung, tetapi tuturan antar tokoh dalam novel maupun narasi dalam novel juga dapat diteliti. Novel Perempuan Berkalung Sorban karya Abidah El Khalieqy digunakan sebagai sumber data penelitian ini karena novel tersebut sangat kental dengan budaya pesantren, sehingga tuturan antar tokoh masih dalam konteks yang sama. Selain itu, jarak sosial antar tokoh yang terdapat dalam novel tersebut jelas untuk diteliti.

\section{B. METODE PENELITIAN}

Metode penelitian yang digunakan pada penelitian ini adalah menggunakan jenis deskriptif kualitatif. Penelitian deskriptif kualitatif bertujuan untuk mengungkapkan informasi dalam bentuk kualitatif dengan pendeskripsian yang teliti dan penuh nuansa untuk menggambarkan secara cermat sifat-sifat suatu hal, keadaan, fenomena, dan tidak terbatas pada pengumpulan data melainkan meliputi analis is interpretasi data (Sutopo, 2002:137).

Metode kualitatif yaitu metode yang memanfaatkan cara-cara penafsiran data dengan menyajikannya ke dalam sebuah bentuk deskripsi makna teks. Bentuk dari penelitian ini adalah studi kepustakaan, yang berarti data yang menjadi penunjang dari penelitian ini dikumpulkan melalui telaah kepustakaan. Teknik pengumpulan data tersebut dilakukan dengan cara menganalisis atau mencatat dokumen yang ada, dengan langkah yang pertama adalah membaca secara berulang objek yang akan diteliti, yaitu novel Perempuan Berkalung Sorban karya Abidah El Halieqy. Kedua, mengklasifikasikan tindak tutur yang ada dalam novel tersebut, dan mengkaji atau menganalis is implikatur yang terdapat dalam tindak tutur novel tersebut.

Sumber data primer yang digunakan sebagai objek dalam penelitian ini adalah novel Perempuan Berkalung Sorban (Edisi Revisi) yang ditulis oleh Abidah El Khaliqy dan diterbitkan oleh Arti Bumi Intaran. Novel ini merupakan cetakan kedua, yang dicetak pada bulan Juli 2008. Novel PBS terdapat 319 halaman yang terbagi menjadi 7 bagian di dalamnya. Sumber lain yang digunakan adalah buku, jurnal, dan artikel. Sumber data lain yang digunakan dalam penelitian ini adalah merujuk pada buku, artikel, dan lain-lain yang relevan dengan penelitian ini.

\section{PEMBAHASAN}

Tindak tutur dapat diteliti melalui ujaran-ujaran yang dikeluarkan oleh seseorang. Ujaran tokoh dalam sebuah cerita seperti novel juga dapat diteliti tindak tuturnya. Tindak tutur yang diteliti dalam penelitian ini yaitu tindak tutur lokusi, ilokusi, dan perlokusi. Tindak tutur ilokusi dibagi menjadi lima bagian yakni; representatif, direktif, ekspresif, komisif, dan deklaratif. 


\title{
Lokusi
}

Tindak tutur lokusi adalah tindak tutur yang maksud di dalamnya semata hanya ingin menyatakan sesuatu yang sesuai dengan suatu tuturan yang dituturkan penutur tanpa adanya maksud lain di dalam tuturan tersebut. Tindak tutur lokusi yang lazim tidak mempermasalahkan fungsi dan maksud dari tuturan atau ujaran yang disampaikan oleh penutur. Tindak tutur lokusi ini relatif lebih mudah untuk diidentifikasi dikarenakan pengidentifikasian tindak tutur lokusi cenderung dilakukan tanpa perlu menyertakan konteks dari tuturan yang tercakup dalam kondisi dan situasi tuturan. Berikut ini adalah salah satu contoh tuturan yang diambil dari novel Perempuan Berkalung Sorban:

\begin{abstract}
"Memang Lekku itu lulusan Gontor. Sudah hampir dua tahun ini ia kuliah di Al-Azhar, Kairo. Ia sering mengirimiku photo, buku, kaset, juga baju-baju bagus. Surat-suratnya indah, banyak puisinya. Ia bilang...sst! Tetapi rahasia lho, katanya ia sering kangen padaku. Suratnya yangterakhir mengatakan suatusaatnanti, ia juga inginmengajakku ke Kairo. Liburan kemarin ia ke Berlin danmengirimiku kaset Mozart (PBS, 2008:60)."
\end{abstract}

Percakapan tersebut berupa percakapan antara penuturnya adalah Nisa, kawan tuturnya adalah Aisyah yang merupakan sahabat Nisa. Tuturan tersebut semata hanya bersifat informatiif yang disampaikan peutur kepada kawan tutur tanpa adanya kecenderungan tertentu untuk melakukan sesuatu atau memprovokasi kawan tutur. Tuturan tersebut disampaikan oleh Nisa (penutur) kepada Aisyah (kawan tutur) semata hanya untuk memberitahukan keberadaan dan pengalaman mengenai lelaki yang ia kagumi atau sukai, yaitu Lek Khudori, tidak ada maksud lain yang membuat Aisyah merasa tertarik dengan Lek Khudori.

\section{Ilokusi}

Ilokusi yang diteliti adalah tindak tutur ilokusi yang merujuk pada teori Searle (dalam Rendro 2010: 217-218) yang di dalamnya terdapat tindak tutur ilokusi representatif, direktif, ekspresif, komisif, dan deklaratif yang terdapat dalam novel Perempuan Berkalung Sorban karya Abidah El Khalieqy.

\section{Representatif}

Tindak tutur ilokusi representatif jika dilihat dari data, diketahui bahwa tuturan yang menggunakan tindak tutur representatif dimaksudkan tidak tutur tersebut membuat penutur terikat dengan kebenaran atas apa yang dikatannya. Tindak tutur representatif yang terdapat di antaranya; menyatakan, menyebutkan, mengajukan, melaporkan, dan lain-lain. Jadi, kekuatan tuturan pada tindak tutur representatif ini terletak pada tuturan yang disampaikan penutur. Berikut ini adalah salah satu contoh tuturan yang diambil dari novel Perempuan Berkalung Sorban:

"Sebenarnya, Nisa itu masih terlalu muda. Jika orang melihat sosok tubuhnya memang masih seperti anak usia lima belasan. Padahal, ia masih anak-anak, belum baligh. Ia masih terlalu bodoh dan banyak naifnya dalam pergaulan hidupnya (PBS, 2008:89)."

Tuturan tersebut termasuk ke dalam tindak tutur representatif (menyatakan), karena tuturan tersebut disampaikan oleh Ayah Nisa, yaitu Kiai Haji Hanan Abdul Malik dengan konteks yang bertujuan untuk menyatakan sifat Nisa di usia lima belas kepada calon mertua Nisa yang ingin menjodohkan anaknya (Samsudin) dengan Nisa, yang mana calon mertuanya adalah teman dari Ayah Nisa. Jarak sosial antara penutur, yaitu Ayah 
Nisa dan kawan tutur, yaitu calon mertua Nisa adalah seusia, maka Ayah Nisa menyampaikan hal tersebut tanpa canggung karena jarak sosial adalah antara teman dengan teman. Terkait budaya, budaya yang digambarkan adalah perjodohan dalam pesantren, yang mana itu lazim dilakukan di lingkungan pesantren.

\section{Direktif}

Tindak tutur ilokusi direktif jika dilihat dari data, diketahui bahwa tuturan yang menggunakan tindak tutur direktif dimaksudkan agar kawan tutur terpengaruh atau melakukan tindakan yang dituturkan atau diujarkan oleh penutur. Tindak tutur direktif yang terdapat di antaranya; menyuruh, memohon, menuntut, menyarankan, menentang, dan lain-lain. Jadi, tindak tutur direktif brmaksud meyakinkan dan mempengaruhi kawan tutur. Semakin kuat ujaran atau tuturan yang disampaikan penutur, maka akan berpengaruh dengan tindak lanjut kawan tutur. Berikut ini adalah salah satu contoh tuturan yang diambil dari novel Perempuan Berkalung Sorban:

"Sudah! Sudah! Dasar perempuan gila. Aku tak perlu bicara denganmu, dengan lidah kasarmu! Aku muak! Aku menyesal telah menikahimu, wanita lancang. Dasar... (ia menyebut kata-kata kotor yang sulit kutirukan di sini) Oke! Mulai hari ini, kita akan tidur terpisah dan jangan coba-coba untuk menasihatiku, lidah ular! (PBS, 2008:115)"

Tuturan tersebut termasuk ke dalam tindak tutur direktif (menuntut), karena tuturan tersebut disampaikan Samsudin yang bertujuan untuk menutut istrinya untuk tidur terpisah, karena perdebatan yang sebelumnya dilakukan oleh Nisa (sang istri) dan Samsudin. Tindak tutur direktif dikatakan menuntut karena diperdebatan sebelumnya Nisa memaparkan keburukan Samsudin, lalu kemudian Samsudin menuntut untuk tidur terpisah. Tuturan sebelumnya adalah sebagai berikut:

"Kedua, sekian waktu kau telah menyakitiku dan berusaha menularkan penyakitmu kepadaku. Tetapi, Allah menjagaku dari kedhalimanmu. Maka kepada Allah jua kuserahkan balasan yang setimpal atas semua aniayamu dan yang ketiga..."

"Cukup! Cukup, kataku. Aku tak mau mendengar ocehan perempuan gila!”

"Yang ketiga...” (PBS, 2008:115)

Terlihat dari tuturan tersebut bahwa Samsudin terpengaruh oleh ujaran atau tuturan Nisa, sehingga ia memutuskan untuk pisah tidur. Jarak atau hubungan sosial yang dilakukan oleh keduanya adalah suami dan istri. Terkait ujaran Nisa kepada Samsudin, Nisa termasuk istri yang berani kepada suami karena perlakuan Samsudin kepada dirinya kurang baik, yang mana hal tersebut bertolak belakang dengan budaya yang ada dalam novel tersebut, yaitu budaya pesantren. Tetapi dalam hal ini, secara konteks penulis novel mengangkat ideologi feminisme, yang menyebabkan tokoh Nisa berani menyuarakan haknya.

\section{Ekspresif}

Tindak tutur ilokusi ekspresif jika dilihat dari data, diketahui bahwa tuturan yang menggunakan tindak tutur ekspresif dimaksudkan agar tuturan yang disampaikan penutur dijadikan sebagai evaluasi mengenai hal yang telah dipaparkan pada tuturan tersebut. Tindak tutur 
ekspresif yang terdapat di dalamnya antara lain; mengucapkan terima kasih, memuji, mengeluh, mengkritik, dan lain-lain. Jadi, dalam hal ini sikap atau psikologis penutur mengenai suatu keadaan dapat terlihat oleh kawan tutur. Berikut ini adalah salah satu contoh tuturan yang diambil dari novel Perempuan Berkalung Sorban:

"Selain ganteng, ia juga sopan sekali. Kudengar ia sering bicara bahasa Arab dengan Mas Saipul. Entahlah. Aku nggak paham omongan mereka hidupnya (PBS, 2008:60)."

Terlihat dari tuturan tersebut bahwa penuturnya adalah Nisa, kawan tuturnya adalah Aisyah yang merupakan sahabat Nisa. Tuturan Nisa berupa tindak tutur ekspresif (memuji), yakni memuji Lek Khudori yaitu saudara jauh Nisa, guru ngaji Nisa, dan pada akhir cerita menjadi suami Nisa setelah Nisa bercerai dengan Samsudin. Selain itu, konteks lain pada tuturan tersebut adalah Nisa mengagumi Lek Khudori dengan diamdiam. Jarak sosial antara penutur dengan kawan tutur adalah teman dengan teman. Budaya yang dimunculkan pada novel tersebut adalah budaya islami, sehingga sangat fatal jika perempuan dan laki-laki mengungkapkan rasa sukanya secara terang-terangan. Maka dari itu, Nisa mengagumi Lek Khudori dalam diam dan hanya bercerita kepada sahabatnya, yaitu Aisyah.

\section{Komisif}

Tindak tutur ilokusi komisif jika dilihat dari data, diketahui bahwa tuturan yang menggunakan tindak tutur komisif dimaksudkan untuk mengikat penuturnya untuk melaksanakan apa yang dituturkan dalam tuturannya. Tindak tutur ekspresif yang terdapat di dalamnya antara lain; mengancam, bersumpah, berjanji dan lain-lain. Berikut ini adalah salah satu contoh tuturan yang diambil dari novel Perempuan Berkalung Sorban:

"Asal tidak diulangi dan mau berjanji."

"Katakan, Mas. Janji untuk apa?"

"Untuk tidak mudahmenelanfitnahdanmenjadi perempuan tegar seperti Fathimah

Zahra atau Maryam al Bathul."

"Aku janji, Mas. Akujanji. Danaku akan berusaha menepati janjiku semampuku.

Tetapi Mas juga harus menolongku untuk itu ya? (PBS, 2008:282)"

Terlihat dari tuturan tersebut bahwa penuturnya adalah Nisa dan kawan tuturnya adalah Lek Khudori yang merupakan saudara jauh Nisa, guru ngaji Nisa, dan pada akhir cerita menjadi suami Nisa. Tuturan Nisa berupa tindak tutur komisif (berjanji), yakni berjanji kepada Lek Khudori agar tidak mendengar fitnah orang lain. Selain itu, konteks lain pada tuturan tersebut adalah Nisa yang awalnya percaya dengan fitnah orang lain, diyakinkan oleh Lek Khudori sehingga berjanji untuk tidak lagi percaya. Jarak sosial antara penutur dengan kawan tutur adalah suami dan istri, yang mana saat itu Nisa sudah menikah dengan Lek Khudori pascaperceraian dengan Samsudin. Budaya yang ada pada tuturan tersebut adalah janji yang disampaikan Nisa seharusnya ditepati, sebagaimana keduanya adalah kaum intelektual juga novel tersebut berlatarkan pesantren. 


\section{Deklaratif}

Tindak tutur ilokusi deklaratif jika dilihat dari data, diketahui bahwa tuturan yang menggunakan tindak tutur deklaratif dimaksudkan agar tuturan yang disampaikan penutur dilakukan agar dapat menciptakan hal yang baru. Tindak tutur deklaratif yang terdapat di dalamnya antara lain; mengizinkan, melarang, membatalkan, memutuskan, memberi maaf, dan lain-lain. Jadi, dalam hal ini tindak tutur deklaratif membuat kawan tutur menghasilkan perubahan dalam waktu singkat melalui tuturan penutur atau menghasilkan akibat pada kawan tutur yang sesuai dengan realitas. Berikut ini adalah salah satu contoh tuturan yang diambil dari novel Perempuan Berkalung Sorban:

"Ow... Ow... Ow... jadi begitu. Apa Ibu belum mengatakan padamu kalau naik kuda hanya pantas dipelajari oleh Kakakmu Rizal, atau Kakakmu Wildan. Kau tahu, mengapa? Sebab kau ini anak perempuan, Nisa. Nggak pantas, anak perempuan kok naik kuda, pencilakan, apalagi keluyuran mengelilingi ladang sampai ke blumbang segala. Memalukan! Kau ini sudah besar masih bodohjuga, hehh!!!" Tasbih bapak bergerak lamban, mengena kepalaku (PBS, 2008:7)."

Terlihat dari tuturan konteks tuturan tersebut bahwa penuturnya adalah Ayah Nisa, yaitu Kiai Haji Hanan Abdul Malik dan kawan tuturnya adalah. Tuturan Ayah Nis a berupa tindak tutur deklaratif (melarang), melarang Nisa sebagai perempuan untuk naik kuda, karena menurut Ayah Nisa yang berkuda adalah kaum laki-laki saja, hal itu juga disebabkan karena dalam konteks novel ini berlatarkan pesantren. Nisa sebagai perempuan hanya diperbolehkan belajar dan membantu pekerjaan rumah saja. Jarak sosial antara penutur dengan kawan tutur adalah orang tua dan anak, yang mana sangat berjarak, Nisa seharusnya lebih santun kepada ayahnya, terlihat juga nada bicara Ayah Nisa yang tinggi, mengartikan bahwa ia marah kepada Nisa. Budaya yang tertanam pada novel tersebut adalah budaya pesantren. Ayah Nisa adalah seorang pemimpin pesantren. Nisa harus menjaga nama baik keluarga. Keluarga Nisa merasa tidak pantas jika Nisa harus berkuda, menurut ayahnya yang pantas untuk berkuda adalah hanya kakak-kakak Nisa, yang mana mereka berjenis kelamin laki-kaki.

\section{Perlokusi}

Tindak tutur perlokusi adalah tindak tutur yang disampaikan oleh penutur kepada kawan tutur yang seringkali memiliki pengaruh atau efek untuk kawan tutur. Efek atau pengaruh tersebut dapat secara langsung atau secara tidak langsung dikreasikan oleh si penutur. Berikut ini adalah salah satu contoh tuturan yang diambil dari novel Perempuan Berkalung Sorban:

"Jodoh itu memang di tangan Tuhan, tapi perceraian itu di tangan manusia. Kalau memang terus disiksa dan disakiti, seorang suami atau istri bisa memutuskan sendiri persoalan itu. Bukankah tidak ada ayat yang menyatakan bahwa perceraian itu urusan Tuhan (PBS, 2008:178)."

Percakapan tersebut berupa percakapan antara penuturnya adalah Lek Khudori, kawan tuturnya adalah Nisa yang saat itu mereka belum memiliki status suami istri, sedangkan Nisa masih diambang batas perceraian dengan Samsudin, suaminya. Tuturan tersebut bukan semata hanya bersifat informatif saja, melainkan juga bertujuan untuk memberikan efek atau 
pengaruh kepada kawan tutur yang pada saat itu Nisa sedang bimbang dalam pernikahannya. Lek Khudori menjelaskan pengenai jodoh dan perceraian, sehingga mempengaruhi pikiran Nisa untuk bercerai atau tidak dengan suaminya, Samsudin.

\section{KESIMPULAN}

Berdasarkan hasil analis is terhadap data penelitian tersebut, maka dapat disimpulkan bahwa tindak tutur dapat diteliti melalui ujaran yang diujarkan oleh tokoh dalam sebuah novel maupun narasi dalam novel yang dibuat oleh pengarang novel. Pada penelitian ini ditemukan berbagai tindak tutur, di antaranya lokusi, ilokusi, dan perlokusi. Lalu, terdapat pula tindak tutur ilokusi representatif, direktif, deklaratif, ekspresif, dan komisif yang terdapat dalam tindak tutur ilokusi.

Tindak tutur dalam setiap tuturan penutur tentunya tetap memperhatikan konteks, budaya dan jarak sosial. Seperti dalam novel Perempuan Bekalung Sorban karya Abidah El Khalieqy yang dijadikan sumber data penelitian. Novel tersebut memiliki latar budaya pesantren, sehingga tuturan antar tokoh atau narasinya agamis dan sopan. Selanjutnya, itu juga berkaitan dengan tuturan jarak sosial antar tokoh yang lebih muda kepada yang lebih tua. Sedangkan, konteks yang diperhatikan adalah siapakah penutur dan kawan tuturnya serta waktu atau momen tuturan yang mereka tuturkan. Sehingga, dapat dikatakan bahwa tindak tutur dapat diteliti dengan tuturan orang-orang di sekitar kita, tentunya dengan memperhatikan konteks, budaya, dan jarak sosial pula.

\section{DAFTAR PUSTAKA}

DS, Rendro. 2010. Beyond Borders: Communication Modernity \& History. Jakarta: Publis her STIKOM The London School of Public Relation.

Khalieqy, Abidah El. 2008. Perempuan Berkalung Sorban. Yogyakarta: Arti Bumi Intaran.

Kushartanti, dkk. 2007. Pesona Bahasa: Langkah Awal Memahami Linguistik. Jakarta: Gramedia Pustaka Utama.

Nurgiyantoro, Burhan. 2017. Teori Pengkajian Fiksi. Yogyakarta: Gadjah Mada University Press.

Siddiq, Mohammad. 2019. "Tindak Tutur dan Pemerolehan Pragmatik pada Anak Usia Dini”. Dalam Jurnal Kredo Vol. 2, No. 2. April.

Sutopo, H.B. 2002. Metodelogi Penelitian Kualitatif Dasar Teori dan Terapannya dalam Penelitiani. Surakarta: Sebelas Maret University Press.

Umaroh, Liya, dan Neni Kurniati. 2017. 'Dominasi Ilokusi dan Perlokusi dalam Transaki Jual Beli’. Dalam Jurnal Lensa: Kajian Kebahasaan, Kesusastraan dan Budaya, Vol. 7, No. 1 .

Warisman. 2016. Membumikan Pembelajaran Sastra yang Humanis. Malang: Universitas Brawijaya Press.

Wibowo, Wahyu. 2009. Menuju Jurnalisme Beretika: Peran Bahasa, Bisnis, dan Politik di Era Modern. Jakarta: PT Kompas Media Nusantara. 